\title{
Socially Responsible Public Procurement and Set-Asides: a Comparative Analysis of the US, Canada and the EU
}

\author{
Carol Cravero* \\ Department of Law, University of Turin; \\ CDRP, University of Paris Nanterre
}

\begin{abstract}
Public procurement can be used to achieve goals other than purely economic ones. Such goals are often referred to as "social linkages". A preference for social considerations has been gaining ground against the dominant best value for money (BVM) paradigm over the past few decades. In the past, public procurement policies followed the principle of non-discrimination and free competition beyond national boundaries. Today considerations other than (purely economic) BVM have become relevant in public procurement policy and practice. Examples of social linkages in public procurement are found in various countries, from the well-known 'Affirmative Action Programs' in the US that advance minorities, women, persons with disabilities and veterans, ${ }^{1}$ to specific set-aside programs made available to only less-competitive businesses, such as womenowned businesses, minority-owned businesses, businesses operating in economically disadvantaged areas, etc. Set-asides can be seen as social procurement linkages through the promotion of both supplier diversity and employment. The latter means that social use of public procurement can positively impact employment by providing opportunities to workers who are generally excluded from the labour market, while the former means that chances are given to less-competitive bidders. Set-aside programs have been widely developed in the US, which has a long tradition of set-aside contracts for special classes of small businesses, including small disadvantaged businesses, and in Canada where set-asides have been introduced for the development of Aboriginal businesses. However, the restriction of full and open competition that set-asides entail is frequently criticized by EU institutions. Despite this, the new European procurement framework also seems to have established set-asides as a means of providing economic opportunities to disadvantaged groups.
\end{abstract}

Keywords: Sustainable Public Procurement; Socially Responsible Public Procurement (SRPP); Set-asides; Best Value for Money (BVM); Disadvantaged Employees; Indigenous Communities; Sheltered Workshop; US Small Business; Canadian Procurement Strategy for Aboriginal Business (PSAB); European Public Procurement Directives

Responsible Editor: Margherita Paola Poto, K.G. Jebsen Center for the Law of the Sea, UiT The Arctic University, Tromsø, Norway

Received: April 2017; Accepted: June 2017; Published: November 2017

${ }^{\star}$ Correspondence to: Carol Cravero, Via Carlo Emanuele III, 35, 12100 Cuneo, Italy. Email: carol. cravero@gmail.com 


\section{Introduction}

Every year, governments spend huge amounts of money for the purchase of goods, services and works from the private sector. Accounting for 15-20\% of global GDP, "public procurement represents a substantial portion of the EU economy and the economies of many countries around the world". ${ }^{2}$ The same holds true for public procurement commitments under the World Trade Organization's Agreement on Public Procurement (GPA), which have been estimated at around EUR 1.3 trillion. $^{3}$

Traditionally, a main aim of public procurement was to achieve best value for money (BVM), limiting the risk of improper conduct on the buyer's side. Along with this, in many countries, and not just in times of crisis, public procurement was also seen as a lever of industrial policy, including local development. In this context, vast and complex set-aside schemes were created in the US and other countries to benefit specific sets of bidders.

Legal integration at the regional level and neo-liberalism pushing for free trade at the global level have naturally been very suspicious of the use of the public procurement lever for industrial policy aims, which are inevitably thought to be tainted by protectionism. They have unconditionally pushed for (purely economic) BVM as a tool to ensure fair competition among domestic and foreign bidders.

However, in the past few decades, considerations other than (purely economic) BVM have become relevant in public procurement policies. In particular, environmental and social considerations have been identified as procurement "linkages", meaning that procurement can be used to achieve goals other than the purely economic ones.

Many different social goals can be met through public procurement, such as promoting employment and equal opportunities, inclusion and accessibility. In this context, some domestic legal frameworks have provided specific preferential programs that favor minorities and other disadvantaged socio-economic operators participating in tender procedures.

An example of a preferential program is the set-aside approach, as developed in the US and Canada. Set-aside programs reserve some public contracts for certain categories of bidders. The restriction of full and open competition entailed in set-asides has been frequently criticized by EU institutions and the Commission in particular. ${ }^{4}$

The aim of this paper is to analyze the relationship between preferential programs, particularly set-asides and the social linkages of public procurement. To better focus on this topic, this paper will first analyze the rise of non-purely economic considerations, in particular the social "linkages" of public procurement against the dominant BVM paradigm (2). Then, US and Canadian set-asides will be analyzed with specific reference to the program developed in the US that favors small businesses, and the Canadian program for indigenous entrepreneurs (3).

Finally, we will study the evolving EU legislative framework and chart its evolution from the initially timid (2004) acceptance of a sort of set-aside (sheltered workshops) to the broadening of this opportunity (2014) to sheltered workshops and social cooperatives (4). The paper closes with some conclusions (5). 


\section{The rise of non-purely economic considerations in public procurement against the dominant BVM paradigm}

Huge expenditures (mostly funded by taxpayers, at least in developed countries) on public procurement obviously require a strict set of rules and principles to ensure that purchasers act efficiently in the public interest. Over time, certain principles have been identified as crucial benchmarks for evaluating the extent to which public purchasing meets economic efficiency rules, limiting risks of improper conduct on the buyer's side. To achieve economic efficiency, public procurement has traditionally focused on purely economic best value for money (BVM). This means that contracting authorities have to obtain the quality and quantity of what they need at the lowest possible price through transparent, accountable and efficient procurement procedures. A purely economic approach to public procurement has traditionally been seen as a guarantee of compliance with sound management of public funds.

In many countries and not just in times of crisis, public procurement has also been seen as a lever of industrial policy, including local development. In particular, public procurement was perceived much more frequently as an instrument "intimately involved in securing national economic" policies. ${ }^{5}$ In fact, as some authors have argued, public procurement was used chiefly to meet domestic economic and political goals such as stimulating national economic activity, protecting national industries against foreign competition and improving the competitiveness of certain industrial sectors. ${ }^{6}$

In this context, several domestic procurement regimes, such as geographic preference rules, were conditioned for protectionism. For instance, the 1933 Buy American Act (BAA) required the US government to prefer US-made products in its purchases and prohibited the acquisition of foreign goods by federal agencies by requiring that:

only unmanufactured articles, materials, and supplies that have been mined or produced in the United States, and only manufactured articles, materials, and supplies that have been manufactured in the United States substantially all from articles, materials, or supplies mined, produced, or manufactured in the United States, shall be purchased for public use. ${ }^{7}$

Moreover, vast and complex set-aside schemes were created in the US to reserve certain public contracts to specific bidders, namely small businesses. ${ }^{8}$

However, with the rise of neo-liberalism and legal integration at the regional level, this protectionism-oriented approach began to be perceived as a policy against free trade at the global level and as undermining the "fundamental business-based and value-oriented underpinnings of successful procurement regimes". ${ }^{9}$ Greater attention has increasingly been paid to the enforcement of openness, competition and non-discrimination procurement principles beyond national boundaries. In this context, (purely economic) BVM has been seen as a tool to ensure fair and open competition among domestic and foreign bidders.

Within the framework of the World Trade Organisation (WTO) system, this need for "greater liberalization and expansion of world trade" led to the Agreement on 
Government Procurement (GPA). ${ }^{10}$ This multilateral agreement was signed in 1994 and revised in 2014 by a number of WTO members. Its fundamental aim is to "mutually open government procurement markets among its parties". ${ }^{11}$ Pursuant to it, national measures that afford protection to domestic suppliers, goods or services, or that discriminate among foreign suppliers, goods or services, are considered as being against the Agreement. ${ }^{12}$

The same holds true for the European public procurement framework, where the need for non-discriminatory measures and openness is strongly underlined first and foremost by the EU Treaty, which establishes principles of non-discrimination, free movement of goods, freedom to provide services and freedom of establishment. Additionally, some general principles of law, such as equality of treatment and transparency, have emerged from European Court of Justice case law and are clearly provided for by EU public procurement Directives, which are fully applicable for national above-threshold contracts. As a consequence of this complex legal framework, all national contracting authorities are required to ensure that national and EU bidders are treated equally in an open and fair market. ${ }^{13}$

Based on these principles, public procurement policies used to be aimed primarily at increasing both purchasing economic efficiency -- by obtaining the lowest possible price for goods, services and works -- and market openness -- by strengthening the competition principle beyond national boundaries. ${ }^{14}$ The combination of these two objectives is essential for "sustaining public and private confidence that public funds are being well spent". ${ }^{15}$

However, in the past few decades, considerations other than (purely economic) BVM have become relevant in public procurement policy and practice, especially social and environmental considerations, both of which belong to the "sustainable public procurement" sphere (SPP). This means that public procurement can be used to meet broader political objectives. These non-purely-economic uses of public procurement have been successfully called "linkages", ${ }^{16}$ meaning that contracting authorities may "link" certain policies as conditions to public contracts in order to reach sustainable solutions: the promotion of environmentally sustainable practices, also known as "green procurement", as well as the promotion of socially responsible public procurement (SRPP). The latter includes the promotion of acceptable working conditions (e.g. minimum wages, working time standards, health and safety standards, etc.), social justice and human rights (i.e. employment opportunities for various employee groups, promotion of decent work, compliance with social and labour rights, reduction of the gender pay gap, social inclusion, accessibility and design for all, consideration of ethical and fair trade principles, and corporate social responsibility (CSR), protection against human rights abuse, etc.). ${ }^{17}$

As a consequence of procurement linkages, the classical procurement goals to maximize profits and minimize costs are increasingly perceived as being no longer sufficient in themselves. "In addition to the government's primary procurement goals, such as price, quality, best value, speed, and efficiency, the government has 


\section{Cravero}

secondary procurement goals, which are not directly related to the acquisition process, but they are beneficial to the economy as a whole." ${ }^{18}$ The lowest-possible-price approach seems to have lost its monopoly in procurement policy objectives.

Focusing more on "socially responsible public procurement" (SRPP), five types of "social linkages" have been specifically identified:

The use of procurement as a method of enforcing anti-discrimination law in the employment context (i); the use of procurement to advance a wider conception of distributive justice, particularly affirmative action in employment (ii); the use of procurement as a method to help stimulate increased entrepreneurial activity by disadvantaged groups defined by ethnicity or gender (iii); the inclusion in procurement contracts of requirements to ensure fairness and equality when services are transferred from the public sector to the private sector (iv); and the use of procurement as a means of putting pressure on companies operating in other countries to conform to equality norms $(\mathrm{v}) .^{19}$

Examples of social linkages in public procurement can be taken from different jurisdictions, from the well-known 'Affirmative Action Programs' in the US established in the 1960s to advance minorities, women, persons with disabilities and veterans, to "the promotion of Canadian aboriginal business development by using selective set-asides for federal procurement, to the "preference point system in South Africa addressing several policy goals dealing with historically disadvantaged categories of persons by unfair discrimination on the basis of race, gender or disability", ${ }^{20}$

Among the above-mentioned linkages, we will focus on the use of procurement as a method to stimulate increased entrepreneurial activity by disadvantaged groups defined by ethnicity or gender. In this context, an important difference can be drawn between procurement linkages that promote supplier diversity and linkages in the employment context. ${ }^{21}$ The latter means that social use of public procurement can positively impact employment by providing opportunities to classes of workers, such as disadvantaged workers, who are generally excluded from the labour market. ${ }^{22}$ Moreover, as a social linkage in promoting supplier diversity, social use of public procurement may lead to the involvement of less-competitive bidders that would have no chance in a competitive market.

Two main types of domestic programs can be set up to help disadvantaged economic operators participate in tender processes: preferential and facilitative programs. While the latter seeks to help and encourage specific bidders to participate in public purchasing -- dividing large procurement into reasonably small lots, for instance -- the former, which includes set-aside programs, tends to create concrete business opportunities. ${ }^{23}$

More specifically, set-asides reserve certain public contracts to specific bidders that meet a number of criteria, including small businesses in general (as in the US), as well as specific classes of small businesses, such as minority businesses and other disadvantaged socio-economic operators. ${ }^{24}$ Through set-asides, governments are able to both promote supplier diversity, involving less-competitive bidders, and create employment opportunities for workers who are generally excluded from the 
labour market. In fact, set-aside programs generally involve small or disadvantaged businesses, which, in turn, can provide more employment opportunities to workers generally excluded from the labour market, such as disadvantaged workers or minorities.

However, the legitimacy of the set-asides approach in public procurement is often criticized for its inconsistency with the competition principle. For instance, preference policies and set-asides, in particular, can be seen as discriminatory in the European legal framework.

How these considerations are mediated with purely economic objectives depends very much on choices made in any given jurisdiction.

\section{Set-asides in the US and Canadian public procurement systems}

Set-asides create business opportunities for specific less-competitive bidders, for whom certain public contracts are reserved. Through set-asides, contracting authorities are permitted to limit full and open competition, barring large businesses from bidding for certain contracts made available only to certain specific less-competitive businesses, such as women-owned businesses, minority-owned businesses, businesses operating in economically disadvantaged areas, etc.

While set-asides imply that full and open competition is limited to favour lesscompetitive enterprises that would otherwise have no chance on the open competitive market, they can also be seen as a powerful social "linkage".

Currently, two social linkages can be considered with regard to set-asides: linkages promoting supplier diversity and linkages in the employment context. ${ }^{25}$ The latter means that small businesses involved in set-aside programs impact positively on employment by providing -- to a greater degree than larger and competition oriented businesses can -- employment opportunities to workers who are generally excluded from the labour market, such as disadvantaged workers. ${ }^{26}$ Moreover, as a social linkage in promoting supplier diversity, set-asides lead to the involvement of less-competitive bidders that would have no chance in a competitive market.

Among those national legal frameworks having implemented this strategy (USA, Canada, South Africa, etc.), the United States has a long tradition of set-aside contracts for special classes of small businesses. The notion of small business has grown to include women-owned small business (WOSB), economically disadvantaged women-owned small business (EDWOSB), veteran-owned small business (VOSB), service-disabled veteran-owned small business (SDVOSB), historically underutilized business zone (HUBZone), small disadvantaged business under the Small Business Administration's 8(a) Business Development Program, etc. ${ }^{27}$ Moreover, according to the 1988 Robert T. Stafford Disaster Relief and Emergency Assistance Act (the so-called "Stafford Act"), which amended the earlier 1974 Disaster Relief Act, set-asides can also be provided for local firms during major disasters or emergencies. ${ }^{28}$ 


\section{Cravero}

Under the authority of the Small Business Administration's 8(a) business development program, contracts are set aside for "socially and economically disadvantaged small business concerns," which includes firms at least $51 \%$ owned and unconditionally controlled by Alaskan Native Corporations (ANCs), Indian tribes, Native Hawaiian Organizations (NHOs) or Community Development Corporations (CDCs). ${ }^{29}$ More specifically, while contracts whose value exceeds the so-called "competitive threshold" are supposed to be set aside for 8(a) firms, contracts below that threshold are generally awarded on a sole-source basis, without competition among 8(a) firms. In this context, Alaskan Native Corporations (ANCs) are considered to be the most successful tenderers with at least one-third of all federal contracts awarded through the Small Business Administration's 8(a) business development program.

This broad use of set-asides in the US has been justified by the fact that small businesses have historically been considered the backbone of American culture. ${ }^{30}$ This policy "reflects a national consensus on the importance of small businesses in the national economy", ${ }^{31}$ which was initially provided to primarily satisfy the government interest in supplying during uneasy times of war. ${ }^{32}$ Later on, with the creation of the Small Business Administration in 1953 and the enactment of the Small Business Acts, particularly that of 1958, this policy increasingly evolved into a strategy to benefit small businesses with a percentage of contract value reserved for less-competitive enterprises. $^{33}$

This policy has been clearly incorporated into the Federal Acquisition Regulation (FAR), the primary regulation for the acquisition of supplies and services by all Federal Executive agencies. Under it, the Government's policy is to "provide maximum practicable opportunities in its acquisitions" in favour of small business categories, including the opportunity to "participate as subcontractors in the contracts awarded by any executive agency, consistent with efficient contract performance". ${ }^{34}$ Ensuring that a fair proportion of contracts for supplies and services are placed with small business is a task charged to the Small Business Administration (SBA) ${ }^{35}$

To win a set-aside contract, small businesses must meet specific requirements, primarily related to their size, revenue, and independent ownership. Some certifications, generally in the form of self-declarations, are provided to ensure the company is truly qualified to receive set-aside contracts. "This allows the government to take portions of contracts that would have gone to large businesses and set-aside portions of those contracts for small businesses, effectively reducing the amount of revenue awarded to large businesses." 36

The restriction of eligible bidders through the use of set-asides is open to criticism due principally to the negative impact on the competition principle. However, another type of criticism can be made regarding potential fraud. In fact, "by providing competitive advantages to small businesses, the federal government incentivizes large businesses to fraudulently pose as small businesses", ${ }^{37}$ by falsely self-certifying their small-business quality. So, if too many large companies unlawfully benefit from set-asides at the expense of actual small businesses, this clearly affects the social goals 
of public procurement in supporting supplier diversity and in providing employment opportunities to disadvantaged workers. Indeed, critics have argued that small businesses do not effectively benefit from set-asides, and moreover, self-declarations are not an efficient means of proof to demonstrate compliance with the eligibility criteria for small businesses. ${ }^{38}$

Similar set-asides are also provided in other countries like Canada, where the federal government seeks to help Aboriginal peoples and communities -- namely First Nations, Inuit and Métis -- in "breaking down barriers to more fully participate in, and benefit from, the Canadian economy", enjoying the same opportunities for employment, income and wealth creation as other Canadians. ${ }^{39}$

In this context, the Federal Framework for Aboriginal Economic Development, launched in June 2009, seeks to meet the need to strengthen indigenous entrepreneurship "by promoting a business-friendly economic climate on reserve land and in the North, while improving access to capital and promoting other business opportunities, including procurement" ${ }^{40}$ Procurement opportunities are currently provided through specific mandatory and voluntary set-aside programs introduced by the Procurement Strategy for Aboriginal Business (PSAB). While mandatory setasides concern only federal contracts that serve a primarily Aboriginal population and are worth more than $\$ 5,000$, voluntary set-asides are left to the discretion of federal employees. In the latter case, federal contracting authorities are encouraged to voluntarily set aside opportunities for competition among Aboriginal businesses "whenever practical", meaning where Aboriginal capacity exists and sound contracting management can be assured and maintained. ${ }^{41}$

Aboriginal suppliers must be PSAB registered and self-certify that they meet two main criteria:

At least 51 per cent of the ownership and control must be made by Aboriginal (applicable also for joint ventures in which an Aboriginal business or businesses have at least 51 per cent of the ownership and control), at least 33 per cent of Aboriginal employees if the Aboriginal business has six or more full-time employees. ${ }^{42}$

In addition to self-certifications, compliance with these criteria is also ensured by a 'potential' audit by Consulting and Audit Canada (CAC)..$^{43}$ Evidence of compliance with the above-mentioned requirements is not necessary at the time the bid is submitted. However, the business should have evidence of eligibility "ready in case it is audited". ${ }^{44}$

CAC can conduct two types of audit: pre-award and post-award audits. More specifically, once a decision to set aside a procurement has been reported to the Access to Federal Procurement Directorate at Indian and Northern Affairs Canada (INAC), the auditing authority performs a mandatory pre-award auditing for requirements valued at, or in excess of, $\$ 2$ million, or for requirements below this value when a need has been identified either by the requisitioning entity, the contracting authority, or INAC. The pre-award auditing process can only begin once all 


\section{Cravero}

bids have been received and evaluated by the contracting authority. ${ }^{45}$ The contracting authority informs INAC of the two best-assessed bidders, without disclosing the bid price. Then, the contracting authority receives CAC's results once CAC has performed the audit. If it has been determined that the best-assessed bidder does not comply with the "Requirements for the Set-Aside Program for Aboriginal Business", the next best-assessed bidder is awarded the contract if the bid meets the required conditions. ${ }^{46}$

Successful contractors with set-aside contracts may also be subject to post-award audits of their eligibility and fulfilment of the other requirements. Non-compliance with these requirements or any untrue statements have civil (i.e. non-criminal) consequences including "forfeiture of the bid deposit; retention of the holdback; disqualification of the business from participating in future contracts under the program; and/or termination of the contract". ${ }^{47}$

\section{The evolving EU legislative framework}

The creation of a "level playing field for all businesses across Europe" 48 within an EU Single Market was one of the main aims of the harmonization of European public procurement rules. Legislative harmonization has historically focused on facilitating competition, openness, transparency and non-discrimination through all EU Member States ${ }^{49}$ as core principles of procurement procedures. These objectives are at the heart of the European Union's (EU) "four freedoms" as established in the Treaty on the Functioning of the European Union (TFEU): the free movement of goods, services, capital and people within EU boundaries (Articles 49 and 56). ${ }^{50}$ Member States' governments must ensure that these four freedoms and the principles deriving from them, such as equal treatment, non-discrimination and transparency, are not threatened or breached by national provisions. Moreover, national procedures for public contracts above a certain monetary value must be set up in accordance with EU Public Procurement Directives (2014/24/EU, 2014/23/EU, 2014/25/EU) to ensure that public procurement is open for competition across all EU Member States. ${ }^{51}$ In this context, the main aims of EU public procurement law has historically been competition and economic efficiency, with little regard for objectives other than purely economic ones.

However, some other considerations have recently gained prominence. Over the past few decades, the importance of overarching environmental and societal goals has been recognized more and more. However, while in the past, these goals were identified as "secondary" considerations in public procurement ("in contrast with the primary objective of a procurement of obtaining goods, works or services on the best terms"), ${ }^{52}$ they have been defined as strategic considerations in the evolving European framework. ${ }^{53}$ More specifically, while the previous Directive 2004/18/EC allowed procuring entities in Member States to take "secondary" environmental and social considerations into account, new and powerful terms were introduced 
in the 2014 Directives, such as sustainable procurement and strategic procurement. ${ }^{54}$ These new terms indicate that public procurement is "about more than just saving money". 55

As already pointed out, social strategic policies can go beyond the contractor's compliance with general legal requirements, such as occupational health and safety, and providing broader social benefits. ${ }^{56}$ These benefits can "be limited to work on the contract itself -- for example, a requirement for a contractor to engage a certain proportion of disabled persons on the contract" or "may also extend beyond it" through specific mechanisms. ${ }^{57}$ For instance, a government can limit participation to particular groups by setting aside contracts in favour of them (as the US and Canada do).

Traditionally, the EU has been suspicious of set-asides because they discriminate among economic operators and are therefore contrary to full and open competition. However, under article 19 of Directive $2004 / 18 / \mathrm{EC},{ }^{58}$ replaced by article 20 of new Directive 2014/24/EU, specific set-asides were provided timidly at first, and only for sheltered workshops. Later they were extended to businesses whose main aim is to employ not just disabled workers but any disadvantaged person.

More specifically, the new Public Procurement Directive established that:

\begin{abstract}
Member States may reserve the right to participate in public procurement procedures to sheltered workshops and economic operators whose main aim is the social and professional integration of disabled or disadvantaged persons or may provide for such contracts to be performed in the context of sheltered employment programmes, provided that at least $30 \%$ of the employees of those workshops, economic operators or programmes are disabled or disadvantaged workers. ${ }^{59}$
\end{abstract}

Compared to article 19 of Directive 2004/18/EC, which refers exclusively to workshops providing employment for disabled people, article 20 of the new Directive aims at creating employment and business' opportunities not only for disabled people, but also for disadvantaged persons by reserving public contracts in favour of not just sheltered workshops but all economic operators whose main aim is to socially and professionally integrate disabled or disadvantaged persons. This provision clearly introduces a social linkage in both the employment context and in supplier diversity, pushing for the participation in the tendering process of businesses employing generally excluded categories of workers, such as disabled and disadvantaged people.

However, there are no specifications on how the terms "disabled persons", and particularly "disadvantaged persons", "sheltered workshop" and "sheltered employment programme" should be interpreted. As has already been pointed out (for instance, for the transposition of the 2014 Directives in certain countries) ${ }^{60}$, the legality of the use of the reserve depends on the notions covered by these terms, which need to be defined. This appears to be a national matter if no definitions are provided by the European directives. ${ }^{61}$ However, while domestic regulations should provide for a 


\section{Cravero}

definition, it should be taken into account how far this could jeopardize EU harmonized rules.

For its part, the new EU Directive contents itself with underlining in the Preamble the significant role played by sheltered workshops in guaranteeing equal employment and occupation opportunities for all, including "disabled and disadvantaged persons, such as the unemployed, members of disadvantaged minorities or otherwise socially marginalised groups". ${ }^{62}$

So, while under normal conditions of competition, sheltered workshops or disadvantaged businesses might not be able to obtain contracts, under the new rules they have an improved chance of winning public contracts. This provides an exception to the competition principle based on a socially-oriented justification. In fact, if these less competitive suppliers "were competitive by themselves on an open market, there would be no need for this exception". ${ }^{63}$ Consequently,

it is appropriate to provide that Member States should be able to reserve the right to participate in award procedures for public contracts or for certain lots thereof to such workshops or businesses or reserve performance of contracts to the context of sheltered employment programmes. ${ }^{64}$

In addition to the provision of article 20 of Directive $2014 / 24 / \mathrm{EU}$, article 77 of the same directive states that contracting authorities may also reserve the right to participate in award procedures for certain services in the fields of health, social and cultural services to "organisations which are based on employee ownership or active employee participation in their governance, and for existing organisations such as cooperatives to participate in delivering these services to end users". ${ }^{65}$ The maximum duration of such contracts shall not be longer than three years. ${ }^{66}$

So, although in principle, the EU avoids small business policies that are preferential in nature, "due to concern over the potential for issues such as discrimination and unequal treatment between member nations", ${ }^{67}$ in practice, the new EU Directive supports disadvantaged businesses providing employment for disabled and disadvantaged people, which would have no chance of obtaining a public contract in a competitive market.

However, how a business can demonstrate a socially-oriented aim remains a controversial and unregulated matter at the EU level. There is no requirement in article 20 (or in article 19 of the previous Public Procurement Directive) that sheltered workshops, programs or socially-oriented business must be certified as such. ${ }^{68}$ This implies that Member States can adopt different solutions with the risk of creating a fragmented patchwork. For instance, different national mechanisms can be developed to demonstrate that bidders are indeed sheltered workshops or sociallyoriented businesses that meet specific national standards, which can again breach free movement rules when standards for bidders from certain countries are set higher than those from other countries. 


\section{Conclusion}

Governments "can use their purchasing power to advance conceptions of social justice goals" (also known as social linkages of public procurement). ${ }^{69} \mathrm{In}$ this context, contracting authorities are increasingly permitted to better take social aspects into account when awarding procurement contracts. This can be done on the basis of the best price-quality ratio (BPQR), which goes beyond a purely economic approach (principally based on the BVM), by choosing tenders that "provide more social advantages, such as a company employing the greatest number of long-term unemployed or disadvantaged persons to perform the contract". ${ }^{70}$

Awarding contracts no longer depends on price alone when a company commits to helping integrate disabled and disadvantaged persons. ${ }^{71}$

Set-asides represent a particular preference policy for implementing social linkages in public procurement. By limiting full and open competition, set-asides limit participation in tendering processes to a particular group of bidders. This approach has been widely used in the US and Canada, but has always been treated with suspicion in the EU legal framework. However, set-asides were expressly permitted by the 2004 EU Public Procurement Directives and then broadened by the 2014 Directives.

Set-asides appear to have become a powerful tool for providing economic opportunities for disadvantaged groups in the EU as well. However, the creation of economic and business opportunities they entail is conditioned by requirements which must be verified. As the US experience demonstrates, self-certifications are insufficient to ensure the participation of the intended targeted businesses. Different mechanisms could be provided to improve the effectiveness of set-asides, such as specific registration for social bidders, regular audits and, more generally, guarantees that the contractor is eligible for the set-aside. ${ }^{72}$

\section{References}

Robert D. Anderson and Anna Caroline Müller, The revisedWTO Agreement on Government Procurement (GPA): key design features and significance for global trade and development (WTO Working Paper ERSD-2017-04, 2017), https://www.wto.org/english/res_e/reser_e/wpaps_e.htm (accessed April 23, 2017).

Sue Arrowsmith and Robert D. Anderson, eds., The WTO Regime on Government Procurement: Challenge and Reform, (Cambridge; New York: Cambridge University Press, 2011).

Sue Arrowsmith, "A taxanomy of horizontal policies in public procurement", in Social and Environmental Policies EC Procurement Law. New Directives and New Directions, eds. Sue Arrowsmith and Peter Kunzlik, (Cambridge; New York: Cambridge University Press, 2009).

Sue Arrowsmith, "Horizontal policies in public procurement: a taxonomy", fournal of Public Procurement 10.2 (2010): 149-186.

Rosemary Boyle, "Disability issues in public procurement", in Social and Environmental Policies EC Procurement Law. New Directives and New Directions, eds. Sue Arrowsmith and Peter Kunzlik, (Cambridge; New York: Cambridge University Press, 2009).

Hilde Caroli Casavola, "Global Rules for Public Procurement”, in Comparative Law on Public Contracts/Droit comparé des contrats publics, eds. Jean-Bernard Auby, Hanna Schroder, Ulrich Stelkens, Rozen Noguellou, (Brussels: Bruylant, 2010). 


\section{Cravero}

Roberto Caranta, "Sustainable Procurement", in EU Public Contract Law. Public Procurement and Beyond, eds. Martin Trybus, Roberto Caranta, G. Edelstam (Brussels: Bruylant, 2014).

Roberto Caranta, "Sustainable Public Procurement in the EU", in The law of green and social procurements in Europe, eds. Roberto Caranta and Martin Trybus, (Copenhagen: DJØF Publishing, 2010).

John Mark Clapp, Are Small Business Set-Asides Successful?, http:/www.academia.edu/7353444/Are_Small_ Business_Set-Asides_Successful, 1 (accessed April 23, 2017).

European Commission (SWD(2013) 53 final/2), Guide to the application of the European Union rules on state aid, public procurement and the internal market to services of general economic interest, and in particular to social services of general interest, Brussels, 29.4.2013.

Dacian C. Dragos and Bogdana Neamtu, "Sustainable Public Procurement in the EU: Experiences and Prospects", in Novelties in the 2014 Directive on Public Procurement, eds. Francois Lichere, Roberto Caranta, Steen Treumer, (Copenhagen: DJØF Publishing, 2014).

European Commission Internal Market and Services, EU Public Procurement Legislation: delivering results. Summary of evaluation report, http://www.eipa.eu/files/topics/public_procurement/executive_summary_ en.pdf (accessed April 23, 2017).

Hersh Friedman, "Why small business self-certification should be abolished and replaced: a case against fraud", Fournal of Contract Management 12 (2014): 50.

Jörgen Hettne, "Strategic Use of Public Procurement. Limits and Opportunities", in European Policy Analysis 7 (2013): http://www.sieps.se/sites/default/files/2013_7epa.pdf

Dirk Hoffmann, Social linkages in Public Procurement, 2009, https://lup.lub.lu.se/student-papers/search/publication/1555391 (accessed April 23, 2017).

Claude Jeanrenaud, "Marchés publics et politiques économique" in Regional Impact of Public Procurement, ed. Claude Jeanrenaud, (Grüsch:Verlag Rüegger, 1985).

William Kirkwood, "The evolution of small business preferences in the United States and selected lessons learned for the European Union", EPPPL 4 (2016): 312.

Kate M. Manuel, Competition in Federal Contracting: An Overview of the Legal Requirements, (Congressional Research Service 7-5700, 2011), www.crs.gov, 10 (accessed April 23, 2017).

Christopher McCrudden, Buying social justice: equality, Government Procurement, and Legal Change (New York: Oxford University Press, 2015).

Christopher McCruden, "EC public procurement law and equality linkages: foundations for interpretations", in Social and Environmental Policies EC Procurement Law. New Directives and New Directions, eds. Sue Arrowsmith and Peter Kunzlik, (Cambridge; New York: Cambridge University Press, 2009), 271.

Claire Methven O'brien, Nicole Vander Meulen and Amol Mehra, Public Procurement and Human Rights: A Survey of Twenty Furisdictions, (The International Learning Lab on Public Procurement and Human Rights. Learning Lab, 2016), http://www.hrprocurementlab.org/blog/reports/public-procurement-andhuman-rights-a-survey-of-twenty-jurisdictions/ (accessed April 23, 2017).

Yuhua Qiao, Khi V. Thai and Glenn Cummings, "State and local procurement preferences: a survey", fournal of Public Procurement 9 (2009): 371-410.

Procurement Strategy for Aboriginal Business: Guidelines for Buyers/Government Officials (Contracting Policy Notice 1997-6), http://www.tbs-sct.gc.ca/Pubs_pol/dcgpubs/ContPolNotices/97-6-eng.asp, (accessed April 23, 2017).

Rita Roos, Sustainable Public Procurement: Briefing Note, 2012, http://unpcdc.org/media/390120/spp_brief_ en_2012-02-06.pdf.

Andrew G. Sakallaris, "Questioning the sacred cow: reexamining the justification for small business set asides", Public Contract Law fournal 36.4 (2007): 685-699.

Steven L. Schooner and Christopher R. Yukins, "Public procurement: focus on people, value for money and systemic integrity, not protectionism", in The Collapse of Global Trade, Murky Protectionism, and the Crisis: Recommendations for the G20, eds. Richard Bladwin and Simon J. Evenett (London: Centre for Economic Policy Research, 2009).

Thorsten Schulten et al., Pay and other social clauses in European public procurement. An overview on regulation and practices with a focus on Denmark, Germany, Norway, Switzerland and the United Kingdom, (Düsseldorf: Study on behalf of the European Federation of Public Service Unions - EPSU, 2012), https://www. boeckler.de/pdf/wsi_schulten_pay_and_other_social_causes.pdf (accessed April 23, 2017).

Beate Sjafjell, Anja Wiesbrock, eds., Sustainable Public Procurement Under EU Law: New Perspectives on the State as Stakeholder, (Cambridge; New York: Cambridge University Press, 2016). 
Treasury Board of Canada Secretariat, Procurement Strategy for Aboriginal Business: Guidelines for Buyers/ Government Officials, (Contracting Policy Notice 1997-6), https://www.tbs-sct.gc.ca/pubs_pol/dcgpubs/ contpolnotices/97-6-eng.asp\#disp (accessed April 23, 2017).

U.S. Gov't Accountability Office, Gao-10-673t, Department of Veteran Affairs: Preliminary Observations on Issues Related to Contracting Opportunities for Veteran-owned Small Businesses, 2010, www.gao.gov/new.items/ d10673t.pdf (accessed April 23, 2017).

U.S. Small Business Administration, 8(a) Business Development, www.sba.gov/content/8abusinessdevelopment, (accessed April 23, 2017).

https://www.aadnc-aandc.gc.ca/eng/1100100033498/1100100033499.

https://www.dol.gov/general/topic/hiring/affirmativeact.

https://ec.europa.eu/growth/single-market/public-procurement.

https://www.gov.uk/government/uploads/system/uploads/attachment_data/file/400242/Government_ Response_to_the_Consultation_on_UK_Transposition_of_new_EU_Procurement_Directives_Public_ Contracts_Regulations_2015.pdf.

http://www.telles.eu/blog/2015/3/13/public-contracts-regulations-regulation-20.

http://www.tbs-sct.gc.ca/pubs_pol/dcgpubs/contpolnotices/cpn_96-6-eng.asp.

https://www.wto.org/english/docs_e/legal_e/rev-gpr-94_01_e.htm.

\section{ACKNOWLEDGEMENTS}

The author thanks Professor Roberto Caranta (University of Turin) for his valuable input and support in the writing of this article. This article is the result of the presentation on "Empowering indigenous communities through sustainable public procurement: challenges and best practices" at the "Expert meeting on Good Governance for the conservation of the Arctic Ecosystem" session organized by the K.G. Jebsen Center of the Law of the Sea and the Arctic University of Norway (UiT), as part of Arctic Frontiers 2017. The author gratefully acknowledges Professor Margherita Poto (UiT) for her invitation to this event and her patience and helpful feedback in the writing of this article.

\section{NOTES}

1. https://www.dol.gov/general/topic/hiring/affirmativeact. Affirmative actions include training programs, outreach efforts, and other positive steps. These procedures should be incorporated into the company's written personnel policies. Employers with written affirmative action programs must implement them, keep them on file and update them annually.

2. https://ec.europa.eu/growth/single-market/public-procurement_it (accessed April 23, 2017). In the EU, over 250000 public authorities spend around $14 \%$ of GDP every year to purchase services, works and supplies. Public authorities are the principal buyers in many sectors, including energy, transport, waste management, social protection and the provision of health or education services.

3. https://www.wto.org/english/docs_e/legal_e/rev-gpr-94_01_e.htm; https://ec.europa.eu/ growth/single-market/public-procurement_it (accessed April 23, 2017).

4. The principle of the openness of public procurement markets was confirmed by the International Procurement Instrument as proposed by the European Commission on 29 January 2016. http://ec.europa.eu/growth/single-market/public-procurement/international_it (accessed April 23, 2017).

5. Christopher McCrudden, Buying social justice: equality, Government Procurement, and Legal Change (New York: Oxford University Press, 2015), 13. 
6. Ibid., 25. See also Claude Jeanrenaud. "Marchés publics et politiques économique" in $R e-$ gional Impact of Public Procurement, ed. Claude Jeanrenaud, (Grüsch:Verlag Rüegger, 1985), 151.

7. Yuhua Qiao, Khi V. Thai and Glenn Cummings, "State and local procurement preferences: a survey", fournal of Public Procurement 9 (2009): 371-410.

8. See paragraph 2 below "The set-asides in the US and Canadian public procurement systems".

9. Steven L. Schooner and Christopher R. Yukins, "Public procurement: focus on people, value for money and systemic integrity, not protectionism", in The Collapse of Global Trade, Murky Protectionism, and the Crisis: Recommendations for the G20, eds. Richard Bladwin and Simon J. Evenett (London: Centre for Economic Policy Research, 2009), 88.

10. Robert D. Anderson and Anna Caroline Müller, The revised WTO Agreement on Government Procurement (GPA): key design features and significance for global trade and development (WTO Working Paper ERSD-2017-04, 2017), https://www.wto.org/english/res_e/reser_e/wpaps_e.htm (accessed April 23, 2017). See also Sue Arrowsmith and Robert D. Anderson, eds., The WTO Regime on Government Procurement: Challenge and Reform, (Cambridge; New York: Cambridge University Press, 2011); Hilde Caroli Casavola, "Global Rules for Public Procurement", in Comparative Law on Public Contracts/Droit comparé des contrats publics, eds. Jean-Bernard Auby, Hanna Schroder, Ulrich Stelkens, Rozen Noguellou, (Brussels: Bruylant, 2010), 27-61.

11. https://www.wto.org/english/tratop_e/gproc_e/gp_gpa_e.htm (accessed April 23, 2017).

12. https://www.wto.org/english/docs_e/legal_e/rev-gpr-94_01_e.htm (accessed April 23, 2017).

13. Under article 18 of the Directive $2014 / 24 / \mathrm{EU}$, it is provided that "Contracting authorities shall treat economic operators equally and without discrimination and shall act in a transparent and proportionate manner. The design of the procurement shall not be made with the intention of excluding it from the scope of this Directive or of artificially narrowing competition. Competition shall be considered to be artificially narrowed where the design of the procurement is made with the intention of unduly favouring or disadvantaging certain economic operators. Member States shall take appropriate measures to ensure that in the performance of public contracts economic operators comply with applicable obligations in the fields of environmental, social and labour law established by Union law, national law, collective agreements or by the international environmental, social and labour law provisions listed in Annex X".

14. Christopher McCrudden, Buying social justice: equality, Government Procurement, and Legal Change, 11-14. "Value for money was proclaimed as the basis on which contracts should be allocated. This reflected a desire to secure the biggest bang for the least bucks, but also a belief that government procurement should emulate the procurement practices of the private sector that was (assumed to) operate entirely on the basis of narrow commercial considerations". Moreover, "in a time of pressure on government budget, these economic considerations have become increasingly important as a factor motivating procurement regulation".

15. Steven L. Schooner and Christopher R. Yukins, "Public procurement: focus on people, value for money and systemic integrity, not protectionism", 87. The public confidence in government suffers as long as states "pay too much for what they buy and, all too often, experience greater levels of wasteful spending, inefficient outcomes (often in the form of paying above market prices for, in the worst-case-scenario, substandard goods and services), and, alas, fraud and corruption".

16. Christopher McCrudden, Buying social justice: equality, Government Procurement, and Legal Change, 11-14.

17. Thorsten Schulten et al., Pay and other social clauses in European public procurement. An overview on regulation and practices with a focus on Denmark, Germany, Norway, Switzerland and 
the United Kingdom, (Düsseldorf: Study on behalf of the European Federation of Public Service Unions - EPSU, 2012), https://www.boeckler.de/pdf/wsi_schulten_pay_and_other_social_causes.pdf (accessed April 23, 2017), 6. See also http://ec.europa.eu/; http://ec.europa. $\mathrm{eu} /$ social/main.jsp?langId=en\&catId=89\&newsId=978 (accessed April 23, 2017); European Commission (SWD(2013) 53 final/2), Guide to the application of the European Union rules on state aid, public procurement and the internal market to services of general economic interest, and in particular to social services of general interest, Brussels, 29.4.2013. See also Dirk Hoffmann, Social linkages in Public Procurement, 2009, https://up.lub.lu.se/student-papers/ search/publication/1555391 (accessed April 23, 2017). Christopher McCrudden, Buying social justice: equality, Government Procurement, and Legal Change, 11-30. The "high economic importance of public procurement gives the public sector a significant market power which can be strategically used not only for economic but also for wider social and political [and green] purposes". This implies that public expenditure can be re-oriented "towards solutions that are more compatible with environmental sustainability, promote social policy considerations, or support innovation". Social and environmental requirements should not be seen as "procurement alien factors". See also Beate Sjafjell, Anja Wiesbrock, eds., Sustainable Public Procurement Under EU Law: New Perspectives on the State as Stakeholder, (Cambridge; New York: Cambridge University Press, 2016); Roberto Caranta, "Sustainable Procurement", in EU Public Contract Law. Public Procurement and Beyond, eds. Martin Trybus, Roberto Caranta, G. Edelstam (Brussels: Bruylant, 2014), 165-190; Roberto Caranta, "Sustainable Public Procurement in the EU", in The law of green and social procurements in Europe, eds. Roberto Caranta and Martin Trybus, (Copenhagen: DJØF Publishing, 2010), 15-51.

18. See Hersh Friedman, "Why small business self-certification should be abolished and replaced: a case against fraud”, fournal of Contract Management 12 (2014): 50.

19. Christopher McCrudden, Buying social justice: equality, Government Procurement, and Legal Change, 18.

20. Rita Roos, Sustainable Public Procurement: Briefing Note, 2012, http://unpcdc.org/ media/390120/spp_brief_en_2012-02-06.pdf (accessed April 23, 2017).

21. Christopher McCrudden, Buying social justice: equality, Government Procurement, and Legal Change, 13.

22. Hersh Friedman, "Why Small Business Self-Certification Should be Abolished and Replaced: A Case Against Fraud", 50. It has been said that $65 \%$ of all new job creation occurs through small businesses.

23. William Kirkwood, "The evolution of small business preferences in the United States and selected lessons learned for the European Union”, EPPPL 4 (2016): 312.

24. Ibid., 312 .

25. Christopher McCrudden, Buying social justice: equality, Government Procurement, and Legal Change, 13.

26. Hersh Friedman, "Why Small Business Self-Certification Should be Abolished and Replaced: A Case Against Fraud", 50.

27. The 8(a) Business Development Program is a business assistance program for small disadvantaged businesses. The 8 (a) Program offers a broad scope of assistance to firms that are at least $51 \%$ owned and controlled by socially and economically disadvantaged individuals. See https://uscontractorregistration.com/qualify-for-set-aside-contracts-today/. See also Kate M. Manuel, Competition in Federal Contracting: An Overview of the Legal Requirements, (Congressional Research Service 7-5700, 2011), www.crs.gov, 10 (accessed April 23, 2017).

28. Ibid., 10. The Stafford Act provides that "[i]n the expenditure of Federal funds for debris clearance, distribution of supplies, reconstruction, and other major disaster or emergency assistance activities [...] carried out by contract or agreement with private [entities], preference shall be given, to the extent feasible and practicable, to those organizations, firms, and 
individuals residing or doing business primarily in the area affected by such major disaster or emergency".

29. In 1992, Native Corporations were to be considered "economically disadvantaged" for all purposes of federal law.

30. John Mark Clapp, Are Small Business Set-Asides Successful?, http://www.academia. edu/7353444/Are_Small_Business_Set-Asides_Successful, 1 (accessed Avril 23, 2017). "It has been said that $65 \%$ of all new job creation occurs through small businesses. Consequently the federal government has sought to favor small business to ensure their continued existence. This strategy, although it goes against the basic principles of government contracting which focuses on the best value to the taxpayer, has been implemented through a number of laws that ensure a percentage of all government contracts will be awarded to small businesses by limiting who can bid on those contracts".

31. Hersh Friedman, "Why Small Business Self-Certification Should be Abolished and Replaced: A Case Against Fraud”, 49. See also U.S. Gov't Accountability Office, Gao-10-673t, Department of Veteran Affairs: Preliminary Observations on Issues Related to Contracting Opportunities for Veteran-owned Small Businesses, 2010, www.gao.gov/new.items/d10673t.pdf (accessed April 23, 2017).

32. John Mark Clapp, Are Small Business Set-Asides Successful?, 5-13. "The Defense Production Act of 1950, passed during the Korean War, once again recognized that the preservation of small businesses was important during times of war even if it entailed paying higher prices". In fact, during World War II and the Korean War, it has been necessary "to ensure the availability of products from small businesses in order to assist in the war effort, even if they cost more to acquire". See also Andrew G. Sakallaris, "Questioning the sacred cow: reexamining the justification for small business set asides", Public Contract Law fournal 36.4 (2007): 685-699. "In 1958 the small business set aside changed from a procurement tool intended to benefit the Government to one intended to benefit small businesses themselves".

33. https://www.sba.gov/about-sba/what-we-do (accessed April 23, 2017).

34. Part 19 of the FAR establishes Small Business Programs (Subpart 19.2) and set-asides in particular (Subpart 19.5).

35. Part 19 of the FAR provides Small Business Programs and set-asides in particular.

36. John Mark Clapp, Are Small Business Set-Asides Successful?, 5.

37. "The Government Accountability Office (GAO) and various offices of inspectors general recognize that fraud in small business government contracting is largely a self-certification problem". See Hersh Friedman, "Why Small Business Self-Certification Should be Abolished and Replaced: A Case Against Fraud", 49.

38. John Mark Clapp, Are Small Business Set-Asides Successful?, 5-11; Hersh Friedman, "Why small business self-certification should be abolished and replaced: a case against fraud", 50 .

39. https://www.aadnc-aandc.gc.ca/eng/1100100033498/1100100033499 (accessed April 23, 2017).

40. https://www.aadnc-aandc.gc.ca/eng/1100100033498/1100100033499 (accessed April 23, 2017).

41. https://www.aadnc-aandc.gc.ca/eng/1100100033498/1100100033499 (accessed April 23, 2017). "A contract that is set-aside for Aboriginal Business means that only Aboriginal businesses are acceptable bidders. The Set-Aside program has two parts: the mandatory set-aside and the voluntary set-aside".

42. Appendix B - Government support for aboriginal economic development through federal procurement of the Aboriginal Business Procurement Policy Performance Objectives (Contracting Policy Notice 1996-6), available at http://www.tbs-sct.gc.ca/pubs_pol/dcgpubs/ contpolnotices/cpn_96-6-eng.asp (accessed Avril 23, 2017). An Aboriginal person is an Indian, Métis or Inuit who is ordinarily resident in Canada. Aboriginal person means a Canadian citizen who is ordinarily resident in Canada and who is: 1) registered under the Indian Act; 2) included on a Band List pursuant to the Indian Act; 3) a member of an affiliate of the 
Métis National Council or the Congress of Aboriginal Peoples; 4) enrolled under a comprehensive land claims agreement; 5) a member of an Aboriginal group with a comprehensive land claim that has been accepted by the Government of Canada; or 6) acknowledged by an established Aboriginal community in Canada as having Aboriginal ancestry.

43. See Treasury Board of Canada Secretariat, Procurement Strategy for Aboriginal Business: Guidelines for Buyers/Government Officials, (Contracting Policy Notice 1997-6), https://www.tbssct.gc.ca/pubs_pol/dcgpubs/contpolnotices/97-6-eng.asp\#disp (accessed April 23, 2017).

44. http://www.tbs-sct.gc.ca/pubs_pol/dcgpubs/contpolnotices/cpn_96-6-eng.asp (accessed April 23, 2017).

45. Treasury Board of Canada Secretariat, Procurement Strategy for Aboriginal Business: Guidelines for Buyers/Government Officials, (Contracting Policy Notice 1997-6), https:/www.tbs-sct.gc.ca/ pubs_pol/dcgpubs/contpolnotices/97-6-eng.asp\#disp (accessed April 23, 2017).

46. Treasury Board of Canada Secretariat, Procurement Strategy for Aboriginal Business: Guidelines for Buyers/Government Officials, (Contracting Policy Notice 1997-6), https://www.tbssct.gc.ca/pubs_pol/dcgpubs/contpolnotices/97-6-eng.asp\#disp (accessed April 23, 2017).

47. Treasury Board of Canada Secretariat, Procurement Strategy for Aboriginal Business: Guidelines for Buyers/Government Officials, (Contracting Policy Notice 1997-6), https://www.tbs-sct.gc.ca/ pubs_pol/dcgpubs/contpolnotices/97-6-eng.asp\#disp (accessed April 23, 2017).

48. https://ec.europa.eu/growth/single-market/public-procurement_it (accessed April 23, 2017).

49. European Commission Internal Market and Services, EU Public Procurement Legislation: delivering results. Summary of evaluation report, http://www.eipa.eu/files/topics/public_procurement/executive_summary_en.pdf (accessed April 23, 2017). "Public purchasers cannot be assumed to have the same commercial pressure or organisational incentives in sound management of their expenditure as private sector purchasers subject to strong competition", which has informed varieties of national legislation to which the EU has sought to bring some common principles, facilitating cross-border competition.

50. Consolidated Version of the Treaty on the Functioning of the European Union (TFEU), art. 26 (2), May 9, 2008, O.J. (C115) 47, http://eur-lex.europa.eu/legal-content/EN/ALL/?uri=CELEX:12008E026 (accessed April 23, 2017).

51. Claire Methven O'brien, NicoleVander Meulen and Amol Mehra, Public Procurement and Human Rights: A Survey of Twenty furisdictions, (The International Learning Lab on Public Procurement and Human Rights. Learning Lab, 2016), http://www.hrprocurementlab.org/blog/reports/public-procurement-and-human-rights-a-survey-of-twenty-jurisdictions/ (accessed April 23, 2017).

52. Sue Arrowsmith, "Horizontal policies in public procurement: a taxonomy", in fournal of Public Procurement 10.2 (2010): 149-186.

53. The Commission defined public procurement as a policy strategic instrument to achieve sustainability, and as an essential contribution to the achievement of EU's goal of smart, sustainable and inclusive growth. See also https://ec.europa.eu/growth/single-market/public-procurement (accessed April 23, 2017).

54. Dacian C. Dragos and Bogdana Neamtu, "Sustainable Public Procurement in the EU: Experiences and Prospects", in Novelties in the 2014 Directive on Public Procurement, eds. Francois Lichere, Roberto Caranta, Steen Treumer, (Copenhagen, DJØF Publishing, 2014), 301.

55. Jörgen Hettne, "Strategic Use of Public Procurement. Limits and Opportunities", in European Policy Analysis 7 (2013): http://www.sieps.se/sites/default/files/2013_7epa.pdf (accessed April 23, 2017). According to the Commission's Europe 2020 Strategy "[T]o achieve a sustainable future, we must already look beyond the short term. Europe needs to get back on track. Then it must stay on track. That is the purpose of Europe 2020. It's about more jobs and better lives. It shows how Europe has the capability to deliver smart, sustainable and inclusive growth, to find the path to create new jobs and to offer a sense of direction to our societies".

56. Sue Arrowsmith, "Horizontal policies in public procurement: a taxonomy", 149-186.

57. Sue Arrowsmith, "Horizontal policies in public procurement: a taxonomy", 149-186. 


\section{Cravero}

58. Art. 19 of the previous Public Procurement Directive 2004/18/EC provides that "Member States may reserve the right to participate in public contract award procedures to sheltered workshops or provide for such contracts to be performed in the context of sheltered employment programmes where most of the employees concerned are handicapped persons who, by reason of the nature or the seriousness of their disabilities, cannot carry on occupations under normal conditions".

59. Art. 20 of the Public Procurement Directive 2014/24/EU.

60. See the UK Government Response to the Consultation on UK Transposition of new EU Procurement Directives, https:/www.gov.uk/government/uploads/system/uploads/ attachment_data/file/400242/Government_Response_to_the_Consultation_on_UK_ Transposition_of_new_EU_Procurement_Directives_Public_Contracts_Regulations_2015. pdf (accessed April 23, 2017).

61. http://www.telles.eu/blog/2015/3/13/public-contracts-regulations-regulation-20 (accessed April 23, 2017).

62. Public Procurement Directive 2014/24/EU preamble n. 36.

63. http://www.telles.eu/blog/2015/3/13/public-contracts-regulations-regulation-20 (accessed April 23, 2017).

64. See http://www.gov.scot/Topics/Government/Procurement/buyer-information/SuppBus (accessed April 23, 2017). See also http://www.telles.eu/blog/2015/3/13/public-contractsregulations-regulation-20 (accessed April 23, 2017).

65. Preamble n. 36 of the directive 2014/24/EU. This provision is limited in scope exclusively to certain health, social and related services, certain education and training services, library, archive, museum and other cultural services, sporting services, and services for private households, and is not intended to cover any of the exclusions otherwise provided for by this Directive. Those services should only be covered by the light regime.

66. Art. 77 of the directive 2014/24/EU. "An organisation referred to in paragraph 1 shall fulfil all of the following conditions: (a) its objective is the pursuit of a public service mission linked to the delivery of the services referred to in paragraph 1 ; (b) profits are reinvested with a view to achieving the organisation's objective. Where profits are distributed or redistributed, this should be based on participatory considerations; (c) the structures of management or ownership of the organisation performing the contract are based on employee ownership or participatory principles, or require the active participation of employees, users or stakeholders; and (d) the organisation has not been awarded a contract for the services concerned by the contracting authority concerned pursuant to this Article within the past three years".

67. William Kirkwood, "The evolution of small business preferences in the United States and selected lessons learned for the European Union", 313.

68. Rosemary Boyle, "Disability issues in public procurement", in Social and Environmental Policies EC Procurement Law. New Directives and New Directions, eds. Sue Arrowsmith and Peter Kunzlik, (Cambridge; New York: Cambridge University Press, 2009), 342.

69. Christopher McCruden, "EC public procurement law and equality linkages: foundations for interpretations", in Social and Environmental Policies EC Procurement Law. New Directives and New Directions, eds. Sue Arrowsmith and Peter Kunzlik, (Cambridge; New York: Cambridge University Press, 2009), 271.

70. http://ec.europa.eu/growth/tools-databases/newsroom/cf/itemdetail.cfm?item_ id=8667\&lang=en\&title=Supporting-social-responsibility-in-the-economy-through-publicprocurement (accessed April 23, 2017).

71. http://ec.europa.eu/growth/tools-databases/newsroom/cf/itemdetail.cfm?item_ $\mathrm{id}=8667 \&$ lang=en\&title=Supporting-social-responsibility-in-the-economy-through-publicprocurement (accessed April 23, 2017).

72. Sue Arrowsmith, "A taxanomy of horizontal policies in public procurement", in Social and Environmental Policies EC Procurement Law. New Directives and New Directions, eds. Sue Arrowsmith and Peter Kunzlik, (Cambridge; New York: Cambridge University Press, 2009), 137. 